\title{
A simple non-graphic method for pedigree description and analysis
}

\author{
TAMAR SCHAAP and MAIMON M. COHEN* \\ From the Department of Human Genetics, Hadassah-Hebrew University Medical Center, Ferusalem, Israel
}

SUMMARY The graphic representation of family data for the computation of the coefficients of inbreeding $[\mathrm{F}]$ and relationship $[\mathrm{r}]$ can be replaced by an algebraic method. The organization of family data is facilitated by a data form which can be easily, thoroughly, and correctly completed, even by a layman. The computation of the coefficients is practically automatic and greatly reduces the possibility of error.

Frequently, in the course of genetic counselling, one is confronted with the task of analysing pedigrees in order to calculate the coefficients of inbreeding $[\mathrm{F}]$ and relationship $[\mathbf{r}]$. The classic procedure entails the graphic representation of the pedigree and subsequent summation of relationship pathways [path coefficients] leading to a common ancestor. This method is straightforward when the pedigree in question is relatively simple. However, this technique becomes more complicated, cumbersome, and time consuming in complex pedigrees, containing internal and intersecting loops, where an individual may be a common ancestor by multiple pathways.

This communication describes a procedure that will simplify the calculation of $F$ and $r$ in complex kindreds. The method consists of a non-graphic representation of family data, in which relationships between the members of a pedigree are expressed by simple numerical symbols and algebraic logic. Such representation permits a practically automatic analysis of family trees and direct computation of the coefficients of inbreeding and relationship. A simple computer programme can be written to make these operations feasible by desk computers. Since the procedure uses only vertical relationships, it is suitable for the above-mentioned purposes. It is not helpful in other types of pedigree analysis, e.g. determining the mode inheritance, in which information about horizontal relationships is essential.

* Established Investigator of the Chief Scientist's Bureau, Israel Ministry of Health.

Received for publication 9 April 1976
The method will be described in the computation of the inbreeding coefficient [F] of an individual named 'the propositus'. The derivation of the coefficient of relationship [r] is identical to that of $F$, considering the two persons in question as parents of 'the propositus'. Therefore, $r$ between the parents is equal to twice the $\mathrm{F}$ of 'the propositus'.

\section{Family data form}

The family data form (Table $\mathrm{I}$ ) is constructed from the present generation ('propositus') back through parents, grandparents, etc. Each family member is represented by a number on this form. The numbers 1 and 2 designate the father and mother of 'the propositus' (or those persons whose coefficient of relationship is to be calculated). The digits 1 and 2, when added to the left of an existing number, mean 'the father of' and 'the mother of', respectively. Thus, 11 indicates the paternal grandfather of 'the propositus'; 2212 stands for the maternal grandmother of the maternal grandfather of 'the propositus'. For the sake of convenience, the family data form is divided into two columns, headed 1 and 2 . The numeral 1 indicates patrilineal relationships while 2 indicates matrilineal relationships.

\section{Completing the family data form}

Identification symbols (letters, names, or identitycard numbers) for all available members of the pedigree are filled in the corresponding spaces in the family data form, e.g.: 11-John Doe (meaning, John Doe was the paternal grandfather of 'the 
TABLE I

FAMILY DATA FORM

'The propositus'

\begin{tabular}{|c|c|}
\hline Column 1 & Column 2 \\
\hline $1-$ & $2-$ \\
\hline $\begin{array}{l}11- \\
21-\end{array}$ & $\begin{array}{l}12- \\
22-\end{array}$ \\
\hline $\begin{array}{l}111- \\
211-\end{array}$ & $\begin{array}{l}112- \\
212-\end{array}$ \\
\hline $\begin{array}{l}121- \\
221-\end{array}$ & $\begin{array}{l}122- \\
222-\end{array}$ \\
\hline $\begin{array}{l}1111- \\
2111- \\
1211- \\
2211-\end{array}$ & $\begin{array}{l}1112- \\
2112- \\
1212- \\
2212-\end{array}$ \\
\hline $\begin{array}{l}1121- \\
2121- \\
1221- \\
2221-\end{array}$ & $\begin{array}{l}1122- \\
2122- \\
1222- \\
2222-\end{array}$ \\
\hline $\begin{array}{l}11111- \\
21111- \\
12111- \\
22111-\end{array}$ & $\begin{array}{l}11112- \\
21112- \\
12112- \\
22112-\end{array}$ \\
\hline $\begin{array}{l}11211- \\
21211-\end{array}$ & $\begin{array}{l}11212- \\
21212-\end{array}$ \\
\hline etc. & etc. \\
\hline
\end{tabular}

propositus'). If the identity of the mother of the paternal grandmother of 'the propositus' is unknown, the space opposite 221 is left unfilled. In the case of common ancestry, the same identification symbol will appear in more than one space. Fig. 1 is a classic graphic representation of an imaginary pedigree, with letters used as identification symbols. Table II is the completed family data form for the same pedigree. The parents of 'the propositus', $A$ and $B$ in Fig. 1, appear in the spaces 1 and 2 in

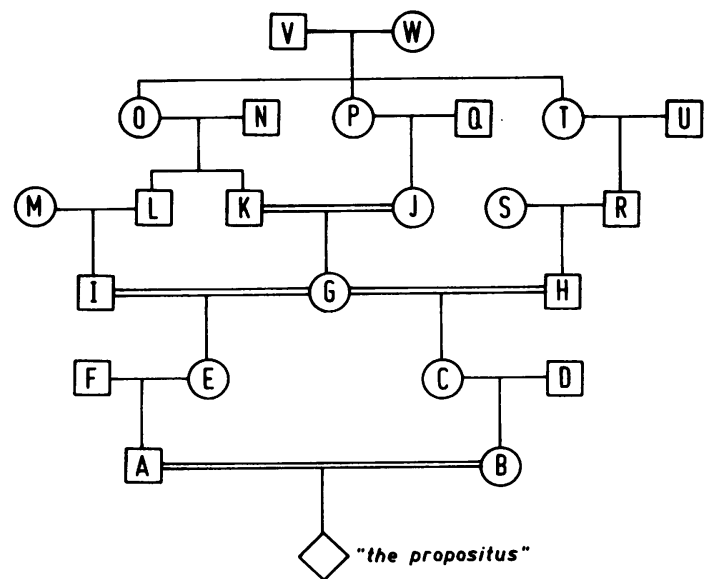

FIG. 1. Graphic representation of the hypothetical family analysed in Table II and III.
TABLE II

FAMILY DATA FORM COMPLETED FOR THE PEDIGREE IN Fig. 1

\begin{tabular}{|c|c|c|c|}
\hline \multicolumn{2}{|c|}{ Column 1} & \multicolumn{2}{|c|}{ Column 2} \\
\hline $\begin{array}{r}1-A \\
11-F \\
21-E\end{array}$ & $\begin{array}{l}111211-- \\
211211-- \\
121211-- \\
221211--\end{array}$ & $\begin{array}{r}2-B \\
12-D \\
22-C\end{array}$ & $\begin{array}{l}111212-- \\
211212-- \\
121212-- \\
221212--\end{array}$ \\
\hline $\begin{array}{l}111-- \\
211-- \\
121-I\end{array}$ & $\begin{array}{l}112211-二 \\
212211-二 \\
122211-二 \\
222211--\end{array}$ & $\begin{array}{l}112-- \\
212-- \\
122-H\end{array}$ & $\begin{array}{l}112212=- \\
212212=- \\
122212=- \\
222212--\end{array}$ \\
\hline $\begin{array}{l}221-G \\
1111-- \\
2111-- \\
1211-- \\
2211--\end{array}$ & $\begin{array}{l}111121-- \\
211121-\overline{ } \\
121121-W \\
221121-V\end{array}$ & $\begin{array}{l}222-G \\
1112-- \\
2112-- \\
1212-- \\
2212--\end{array}$ & $\begin{array}{l}111122-- \\
211122-\bar{W} \\
121122=\mathrm{V} \\
221122-\mathrm{V}\end{array}$ \\
\hline $\begin{array}{l}1121-\mathbf{L} \\
2121-\mathbf{M} \\
1221-\mathrm{K} \\
2221-\mathrm{J}\end{array}$ & $\begin{array}{l}112121-- \\
212121-- \\
122121-- \\
222121--\end{array}$ & $\begin{array}{l}1122-\mathbf{R} \\
2122-\mathrm{S} \\
1222-\mathrm{K} \\
2222-\mathrm{J}\end{array}$ & $\begin{array}{l}112122=- \\
212122=- \\
122122=- \\
222122=-\end{array}$ \\
\hline $\begin{array}{l}11111-- \\
21111=- \\
12111=- \\
22111--\end{array}$ & $\begin{array}{l}111221--\overline{ } \\
211221-\bar{W} \\
121221=\mathrm{V} \\
221221-\mathrm{V}\end{array}$ & $\begin{array}{l}11112-- \\
21112-- \\
12112-- \\
22112--\end{array}$ & $\begin{array}{l}111222-\overline{ } \\
211222-\bar{W} \\
121222=\bar{V} \\
221222-V\end{array}$ \\
\hline $\begin{array}{l}11211-- \\
21211-- \\
12211-\square \\
22211-\square\end{array}$ & $\begin{array}{l}112221-- \\
212221-\bar{W} \\
122221=\mathrm{W} \\
22221-\mathrm{V}\end{array}$ & $\begin{array}{l}11212-- \\
21212-- \\
12212-- \\
22212--\end{array}$ & $\begin{array}{l}112222-- \\
212222-\bar{W} \\
122222-W \\
222222-v\end{array}$ \\
\hline $\begin{array}{l}11121-\mathrm{N} \\
21121-\mathrm{O} \\
12121-- \\
22121--\end{array}$ & & $\begin{array}{l}11122-U \\
21122-\mathrm{T} \\
12122-- \\
22122--\end{array}$ & \\
\hline $\begin{array}{l}11221-\mathrm{N} \\
21221-\mathrm{O} \\
12221-\mathrm{Q} \\
22221-\mathrm{P}\end{array}$ & & $\begin{array}{l}11222-\mathrm{N} \\
21222-\mathrm{O} \\
12222-\mathrm{Q} \\
22222-\mathrm{P}\end{array}$ & \\
\hline $\begin{array}{l}111111-- \\
211111=- \\
121111=- \\
221111=-\end{array}$ & & $\begin{array}{l}111112-- \\
211112-- \\
121112-- \\
221112--\end{array}$ & \\
\hline 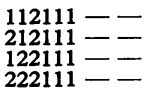 & & $\begin{array}{l}112112-- \\
212112-- \\
122112=- \\
222112--\end{array}$ & \\
\hline
\end{tabular}

Table II. The parents of the individual $\mathrm{F}$ in Fig. 1 are unknown: individual $\mathrm{F}$ occupies the space 11 in Table II and spaces 111 and 211 are accordingly empty. Individual $\mathrm{G}$ is a common ancestor and occupies spaces 221 and 222 in Table II.

\section{Analysing family data}

The identification symbols of column 1 are scanned against those of column 2 . If an identification symbol appears in both columns, the corresponding numbers are written as two sides of an equation, e.g. if 11-John Doe and 112-John Doe, then $11=112$. The analysis of the data from Table II is represented in Table III.

The rules of the game are the following:

(a) Only equations between columns are legitimate. If the same identification symbol appears 
more than once in the same column, but not in the second column, e.g. 11-J.D. and 121-J.D., no equation should be written. As a check, the last digit of both members of the equation must be different.

(b) If the same identification symbol appears in both columns but more than once in any given column, multiple equations will be needed. Thus, if 11-J.D., 121-J.D. and 1122-J.D., then: $11=$ 1122 and $121=1122$ (the equation $11=121$ is illegitimate). All possible equations should be listed and no legitimate equation should be omitted.

(c) Once an equation has been obtained, all the equations that can be derived from it, by the addition of the same digit (or digits) to the left of both numbers in the equation, are trivial and should be discarded. For example, if $211=2222$, then $1211=$ 12222 and $2211=22222$ are trivial and must be eliminated. Table III contains all the legitimate equations for the pedigree in Table II, with the trivial equations crossed out.

\section{Calculating coefficient of inbreeding [F]}

\section{(1) For autosomal loci}

The contribution of each common ancestor to the coefficient of inbreeding is $[1 / 2]^{n-1}$, where $n$ is the total number of digits on both sides of the equation for the particular common ancestor. $F$ then is the sum of the individual contributions of each equation. The third column in Table III lists the values of $n-1$ (the exponent of [1/2]) for each common ancestor in the pedigree appearing in Fig. 1 and Table II. The fourth column in Table III includes the individual contributions of each common ancestor to the coefficient of inbreeding. The sum of these contributions is $\mathrm{F}$. In our particular example,
$\mathrm{F}$ of 'the propositus' is $[1 / 2]^{5}+2[1 / 2]^{9}+12[1 / 2]^{11}=$ 0.041 .

\section{(2) For sex-linked genes}

Since the probability of a male transmitting an $\mathrm{X}$ chromosome to any of his sons is zero, an $\mathrm{X}$ linked gene cannot be identical by descent if two consecutive males appear in the pathway. Such a relationship is represented in our equational notation by the figures 11 . For instance, an equation containing the numerical sequence 121122 indicates a pathway which is noncontributory to the $F$ value of the propositus for X-linked loci. The probability of a male transmitting an $\mathrm{X}$ chromosome to his daughters is 1 . Therefore, a male $\rightarrow$ female sequence in a pathway actually 'shortens' it by one step in the case of X-linked loci. Such relationships are represented by the sequence 12 .

For the actual computation of $F$ values for $X-$ linked loci, first perform steps $a, b$, and $c$ as for autosomal genes. Then,

(d) Discard all equations containing the sequence 11 (signifying male-to-male transmission) (Table III, column 5).

(e) For equations containing one or more sequences of 12 (male to female transmission) subtract 1 from the total of the column headed [ $n-1]$. for each 12 sequence (Table III, column 6).

The calculated $\mathrm{F}$ value of the propositus in Fig. 1 for $\mathrm{X}$-linked genes is :

$$
2[1 / 2]^{8}+2[1 / 2]^{10}+[1 / 2]^{5}=0.041
$$

In this particular pedigree, the ' $F$ ' is identical for both autosomal and sex-linked genes.

As an additional example of the efficacy of this technique, the inbreeding coefficient of the complex

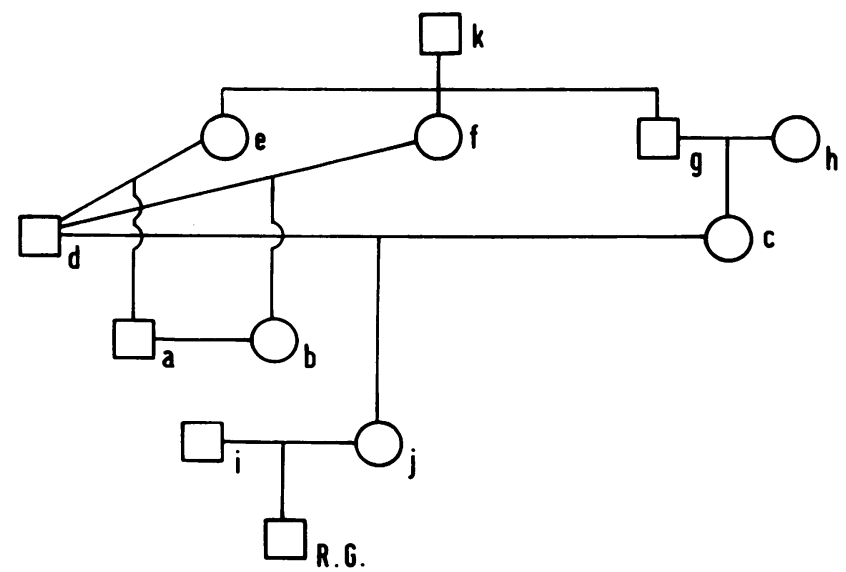

FIG. 2. Graphic representation of the pedigree of 'Roan Gauntlet'. 
pedigree of Roan Gauntlet, including several generation gaps, has been calculated (Fig. 2, Table IV).

\section{Discussion}

Two classes of methods for simplifying the calculation of inbreeding coefficients from complicated pedigrees have been suggested: those designated for computer analysis (Mange, 1969; Maclean, 1969; Yasuda, 1969) and those applicable to hand calculation (Kudo, 1962; Kudo and Sakaguchi, 1963).
Computerized techniques demand encoding of data as an input format and access to the necessary machine components before the analysis can be performed. The extreme flexibility of the suggested method yields several distinct advantages over both of the former techniques. It is basically an openended technique, which places no constraint on the interviewer who can easily construct the data form to meet the requirements of any particular pedigree (Table I).

TABLE III

EQUATIONS FOR COMMON ANCESTORS AND CALCULATION OF F

\begin{tabular}{|c|c|c|c|c|c|c|}
\hline \multirow{2}{*}{$\begin{array}{l}\text { Common } \\
\text { oncestor }\end{array}$} & \multirow{2}{*}{ Equation } & \multicolumn{2}{|c|}{ Autosomal genes } & & \multicolumn{2}{|c|}{$X$-linked genes } \\
\hline & & $n-1$ & $\begin{array}{l}\text { Contribution } \\
\text { to } F \text { volue }\end{array}$ & & $n-1$ & $\begin{array}{l}\text { Contribution } \\
\text { to F value }\end{array}$ \\
\hline G & $221=222$ & 5 & {$[1 / 2]^{5}$} & & 5 & {$[1 / 2]^{5}$} \\
\hline K & $+221=-1222^{*}$ & & & & & \\
\hline$J$ & $2221=-222 z$ & & & & & \\
\hline $\mathrm{N}$ & $11121=11222$ & 9 & {$[1 / 2]^{9}$} & discord & & \\
\hline 0 & $21121=21222$ & 9 & {$[1 / 2]^{9}$} & discard & & \\
\hline$N$ & $+1221=-11222$ & & & & & \\
\hline O & $21221=-21222$ & & & & & \\
\hline$Q$ & $+12221=-12222$ & & & & & \\
\hline$P$ & $22221=-22222$ & & & & & \\
\hline w & $121121=121122$ & 11 & {$[1 / 2]^{11}$} & discord & & \\
\hline w & $+21121=+21222$ & & & & & \\
\hline W & $121121=122222$ & 11 & {$[1 / 2]^{11}$} & discard & & \\
\hline w & $121221=121122$ & 11 & {$[1 / 2]^{11}$} & discard & & \\
\hline W & $+2122+=+21222$ & & & & & \\
\hline w & $121221=122222$ & 11 & {$[1 / 2]^{11}$} & & 8 & {$[1 / 2]^{8}$} \\
\hline W & $122221=121122$ & 11 & {$[1 / 2]^{11}$} & discord & & \\
\hline w & $122221=121222$ & 11 & {$[1 / 2]^{11}$} & & 8 & {$[1 / 2]^{8}$} \\
\hline$w$ & $+22221=+22222$ & & & & & \\
\hline v & $221121=221122$ & 11 & {$[1 / 2]^{11}$} & discord & & \\
\hline v & $221+21=22122 z$ & & & & & \\
\hline v & $221121=222222$ & 11 & {$[1 / 2]^{11}$} & discord & & \\
\hline v & $221221=221122$ & 11 & {$[1 / 2]^{11}$} & discord & & \\
\hline v & $22+221=22+222$ & & & & & \\
\hline v & $221221=222222$ & 11 & {$[1 / 2]^{11}$} & & 10 & {$[1 / 2]^{10}$} \\
\hline v & $222221=221122$ & 11 & {$[1 / 2]^{11}$} & discord & & \\
\hline v & $222221=221222$ & 11 & {$[1 / 2]^{11}$} & & 10 & {$[1 / 2]^{10}$} \\
\hline v & $222221=222222$ & & & & & \\
\hline \multicolumn{4}{|c|}{$\begin{array}{c}F=[1 / 2]^{5}+2[1 / 2]^{9}+12[1 / 2]^{11} \\
=0.041\end{array}$} & \multicolumn{3}{|c|}{$\begin{aligned} F=[1 / 2]^{5} & +2[1 / 2]^{8}+2[1 / 2]^{10} \\
& =0.041\end{aligned}$} \\
\hline * & Crossed out equatio & are + & vial & & & \\
\hline
\end{tabular}


TABLE IV

ALGEBRAIC REPRESENTATION AND CALCULATION OF F IN PEDIGREE OF ROAN GAUNTLET (Fig. 2)

\begin{tabular}{|c|c|c|c|}
\hline \multicolumn{2}{|c|}{ Family Data } & \multicolumn{2}{|c|}{ Calculation of $F$} \\
\hline Column 1 & Column 2 & Equations & $n-1$ \\
\hline $1-i$ & $2-j$ & d $\quad 111=12$ & 4 \\
\hline $\begin{array}{l}11-a \\
21-b\end{array}$ & $\begin{array}{l}12-d \\
22-c\end{array}$ & d $\quad 121=12$ & 4 \\
\hline $\begin{array}{l}111-\mathrm{d} \\
211-\mathrm{e}\end{array}$ & $\begin{array}{l}112-- \\
112--\end{array}$ & $\begin{array}{l}\text { k } \quad 1211=1122 \\
\text { k } \quad 1221=1122\end{array}$ & $\begin{array}{l}7 \\
7\end{array}$ \\
\hline $\begin{array}{l}121-\mathrm{d} \\
221-\mathrm{f}\end{array}$ & $\begin{array}{l}122-g \\
222-h\end{array}$ & \multicolumn{2}{|c|}{$\mathbf{F}=\left(\frac{1}{2}\right)^{4}+\left(\frac{1}{2}\right)^{4}+\left(\frac{1}{2}\right)^{7}+\left(\frac{1}{2}\right)^{7}=0.14062$} \\
\hline $\begin{array}{l}1111-- \\
2111-\overline{ } \\
1211-\mathbf{k} \\
2211--\end{array}$ & $\begin{array}{l}1112-- \\
2112-- \\
1212-- \\
2212--\end{array}$ & & \\
\hline $\begin{array}{l}1121-- \\
2121-\overline{-} \\
1221-\mathbf{k} \\
2221--\end{array}$ & $\begin{array}{l}1122-\mathrm{k} \\
2122-- \\
1222-- \\
2222--\end{array}$ & & \\
\hline
\end{tabular}

The calculation of inbreeding coefficients for sexlinked genes is essentially identical to that for autosomal loci. The addition of two simple steps: (a) the elimination of all equations containing the numerical sequence 11 ; and (b) the reduction of the [n-1] column (Table III-sex-linked genes) by 1 for each sequence of 12 , are easy modifications extending the method to sex-linked genes.

In the classic computation of inbreeding coefficients, persons who themselves are inbred and serve as common ancestors demand special attention through a formula given by Wright (1922): $\mathrm{F}=$ $[1 / 2]^{\mathrm{n}}[1+\mathrm{Fa}]$. In all other methods this equation must be invoked. However, in our method, the application of this formula is totally unnecessary as the degree of inbreeding of the common ancestor is automatically accounted for.

Each equation describing a given common ancestor (Table III) contains all the necessary information concerning that pedigree pathway connecting him with the propositus' parents. Such information, at times difficult to obtain from other methods, may be extremely useful when calculating $F$ values in different intersecting pedigrees with one or more common ancestors that may contain propositi manifesting the same hereditary trait. That particular common ancestor who introduced the segregating gene into the various pedigrees is easily identifiable by searching the column headed 'common ancestor'
(Table III) of the several pedigrees. If the same individual appears repeatedly, he necessarily introduced the gene in question to these kindreds. Such comparisons may also be useful in determining the inheritance pattern of the trait being investigated. If a given individual's contribution to the $F$ value consistently appears in both columns 4 and 7 of Table III, the trait may be either autosomal or $\mathrm{X}$-linked. However, if this contribution is always discarded in column 5, the trait cannot be X-linked.

Perhaps the greatest advantage of the suggested technique is its applicability to either manual or computer execution. In contrast to those methods which are only applicable to computers, our method can be entirely expedited by hand. When used manually, our method proves much simpler and faster than the graphic pedigree designation. If adaptation to computer analysis is desired, then the only human intervention in the entire process is the initial data collection by the interviewer. The data forms (Table II) are directly transcribable as computer input information. Depending on the type and size of computer, memory capacity, computer language, etc. simple programmes can be derived to make the necessary intercolumn comparisons, write the appropriate equations, eliminate the trivial ones, count their digits [n], calculate the exponent of [1/2] for each equation [ $n-1]$ and finally compute $\mathbf{F}$ or $\mathbf{r}$. In this way, without the necessity of drawing a family tree or tracing intricate and often redundant pathways of relationship, pedigree analysis can be achieved in a simple, straightforward, and reliable fashion.

\section{References}

Kudo, A. (1962). A method for calculating the inbreeding coefficient. American fournal of Human Genetics, 14, 426-432.

Kudo, A. and Sakaguchi, K. (1963). A method for calculating the inbreeding coefficient. II. Sex-linked genes. American Fournal of Human Genetics, 15, 473-480.

MacLean, C. (1969). Computer analysis of pedigree data. In International Conference on Computer Application in Genetics, pp. 82-86. Ed. by N. Morton. University of Hawaii Press, Honolulu, Hawaii.

Mange, A. P. (1969). Wright's coefficient of inbreeding, F, for human pedigrees. In International Conference on Computer Applition in Genetics, pp. 72-78. Ed. by N. Morton. University of Hawaii Press, Honolulu, Hawaii.

Wright, S. (1922). Coefficient of inbreeding and relationship. American Natur., 56, 330-338.

Yasuda, N. (1969). Estimation of the inbreeding coefficient from mating type frequency and gene frequency. In International Conference on Computer Application in Genetics, pp. 87-96. Ed. by N. Morton, University of Hawaii Press, Honolulu, Hawaii. 